Lentera Pustaka: Jurnal Kajian Ilmu Perpustakaan, Informasi dan Kearsipan, 5 (1): 49-64, 2019

Copyright @2019, ISSN: 2302-4666 print/ 2540-9638 online

Available Online at: http://ejournal.undip.ac.id/index.php/lpustaka

\title{
Analisis Bibliometrik Jurnal Geologi dan Sumberdaya Mineral Tahun 2014 - 2018
}

\author{
Yupi Royani $^{1 *}$, Rochani Nani Rahayu ${ }^{1}$, Ety Yuliati ${ }^{1}$ \\ ${ }^{1}$ Pusat Data dan Dokumentasi Ilmiah LIPI, Lembaga Ilmu Pengetahuan Indonesia \\ *) Korespondensi: yupi_rdd@yahoo.co.id
}

\begin{abstract}
This research identified the publications pattern of Jurnal Geologi dan Sumberdaya Mineral for the period of 2014 - 2018. By using a bibliometric technique, over 100 articles that were published in $2014-2018$ were collected and analyzed. It shows that the distribution of articles was evenly distributed on each volume and issue number. It was found that the number of articles published as many as 100 titles, where the number of collaborating authors was higher than a single author. The most productive authors were Ronaldo Irzon and Sigit Maryanto, while the most contributed institution was the Center for Geological Survey of the Ministry of Energy and Mineral Resources of the Ministry of Energy and Mineral Resources, which is 73\%, and research trends were related to geological structures.
\end{abstract}

Keywords: geology; geologic structures; sedimentary rocks; basins (geology); geochemistry

\begin{abstract}
Abstrak
Penelitian ini bertujuan untuk mengetahui pertumbuhan publikasi Jurnal Geologi dan Sumberdaya Mineral periode 2014 - 2018. Dengan menggunakan metode bibliometric, penelitian ini menganalisis semua artikel yang diterbitkan oleh Jurnal Pusat Survei Geologi, Kementrian Energi dan Sumber Daya Mineral yang berjudul Jurnal Geologi dan Sumber Daya Mineral periode 2014 - 2018 sebanyak 100 judul. Hasil analisis menunjukkan bahwa sebaran artikel merata pada setiap volume dan nomor terbitan. Dengan jumlah artikel yang dipublikasikan sebanyak 100 judul, ditemukan pula pengarang berkolaborasi lebih banyak dibandingkan pengarang tunggal. Adapun pengarang paling produktif adalah Ronaldo Irzon dan Sigit Maryanto, dengan institusi penyumbang artikel terbanyak adalah Pusat Survei Geologi Badan Geologi Nasional Kementerian ESDM yaitu 73\%, dan tren penelitian adalah berkaitan dengan struktur geologi.
\end{abstract}

Kata kunci: geologi; struktur geologi; batuan sedimentasi; basin (geologi); geochemistry

\section{Pendahuluan}

Di Indonesia ilmu Geologi memegang peranan penting karena Indonesia berada di atas tiga tumbukan lempeng benua, yaitu Indo - Australia dari sebelah selatan, Eurasia dari utara, dan Pasifik dari Timur. Daerah ini juga sering disebut sebagai sabuk gempa Pasifik. Indonesia berada di jalur gempa teraktif di dunia karena dikelilingi oleh Cincin Api Pasifik dan berada di atas tiga tumbukan lempeng benua, yakni, Indo-Australia dari sebelah selatan, Eurasia dari utara, dan Pasifik dari timur. Kondisi geografis ini di satu sisi menjadikan Indonesia sebagai wilayah yang rawan bencana letusan gunung api, gempa, dan tsunami namun di sisi lain menjadikan Indonesia sebagai wilayah subur dan kaya secara hayati (Frank, 2018). Debu akibat letusan gunung berapi menyuburkan tanah sehingga masyarakat tetap banyak yang tinggal di area sekitar gunung berapi. Jalur Cincin Api juga memberikan potensi energi 
tenaga panas bumi yang dapat digunakan sebagai sumber tenaga alternatif (National Geographic Indonesia, 2014)

Menurut catatan Badan Meteorologi Klimatologi dan Geofisika sepanjang 2018, beberapa gempa yang terjadi di Indonesia dapat dilihat dari Tabel 1.

Tabel 1. Daftar Gempa yang terjadi di Indonesia 2018

\begin{tabular}{|c|c|c|c|}
\hline Lokasi & Waktu & $\begin{array}{l}\text { Besaran } \\
\text { (magnitudo) }\end{array}$ & Korban \\
\hline Lebak Banten & 23 Januari 2018 & $\mathrm{M}=6,1$ & $\begin{array}{l}\text { Merusak } 1.231 \text { rumah, } 1 \\
\text { orang meninggal, dan } \\
\text { beberapa orang luka-luka. }\end{array}$ \\
\hline Geumpang Aceh Barat & 8 Februari 2018 & $M=6,3$ & $\begin{array}{l}\text { Merusak } 11 \text { rumah dan } 1 \\
\text { masjid. }\end{array}$ \\
\hline Sumenep & 13 Juni 2018 & $\mathrm{M}=4,80$ & $\begin{array}{l}\text { Merusak } 77 \text { rumah dan } 6 \\
\text { orang luka-luka. }\end{array}$ \\
\hline Lebak Banten & 7 Juli 2018 & $\mathrm{M}=4,4$ & Merusak 28 rumah \\
\hline Muara Teweh & 12 Juli 2018 & $M=4,4$ & Merusak beberapa rumah. \\
\hline Kepulauan Mentawai & 20 Juli 2018 & $M=5,20$ & Merusak 12 rumah \\
\hline Padang Panjang & 21 Juli 2018 & $\mathrm{M}=5,3$ & Merusak 12 rumah \\
\hline Lombok & 29 Juli 2018 & $M=6,4$ & $\begin{array}{l}\text { Merusak rumah dan } \\
\text { menyebabkan orang } \\
\text { meninggal dunia. }\end{array}$ \\
\hline Lombok & 5 Agustus 2018 & $\mathrm{M}=7,0$ & $\begin{array}{l}\text { Merusak rumah dan } \\
\text { menyebabkan orang } \\
\text { meninggal dunia. }\end{array}$ \\
\hline Lombok & 9 Agustus 2018 & $M=5,8$ & $\begin{array}{l}\text { Merusak rumah dan } \\
\text { menyebabkan orang } \\
\text { meninggal. }\end{array}$ \\
\hline Manggarai & 17 Agustus 2018 & $\mathrm{M}=6,2$ & $\begin{array}{l}\text { merusak } 151 \text { rumah dan } \\
\text { beberapa orang luka-luka. }\end{array}$ \\
\hline Lombok & 19 Agustus 2018 & $M=6,2$ & $\begin{array}{l}\text { Total korban meninggal } \\
\text { gempa Lombok mencapai } \\
\text { lebih dari } 555 \text { orang dan } \\
\text { ribuan rumah rusak. }\end{array}$ \\
\hline Donggala dan Palu & 28 September 2018 & $M=6$ & $\begin{array}{l}\text { menyebabkan rumah rusak } \\
\text { dan orang meninggal } \\
\text { dunia. }\end{array}$ \\
\hline Donggala dan Palu & 28 September 2018 & $\mathrm{M}=7,5$ & $\begin{array}{l}\text { menyebabkan rumah rusak } \\
\text { dan orang meninggal } \\
\text { dunia. Total dampak } \\
\text { gempa Donggala dan Palu, } \\
\text { beserta ikutannya yaitu } \\
\text { tsunami dan likuefaksi } \\
\text { mencapai lebih dari } 2.000 \\
\text { orang meninggal, lebih dari } \\
1000 \text { orang hilang dan } \\
\text { merusak ribuan rumah. }\end{array}$ \\
\hline Sumba Timur & 1 Oktober 2018 & $M=6,0$ & $\begin{array}{l}\text { merusak banyak rumah dan } \\
\text { beberapa orang luka. }\end{array}$ \\
\hline Sumba timur & 2 Oktober 2018 & $M=6,4$ & $\begin{array}{l}\text { merusak puluhan rumah dan } \\
3 \text { orang meninggal. }\end{array}$ \\
\hline Mamasa & 3 November 2018 & $\mathrm{M}=4,7$ & menyebabkan beberapa \\
\hline
\end{tabular}




\begin{tabular}{|c|c|c|c|}
\hline Mamasa & 8 November 2018 & $M=4,6$ & $\begin{array}{l}\text { rumah rusak ringan. } \\
\text { menyebabkan beberapa } \\
\text { rumah rusak ringan. }\end{array}$ \\
\hline Sangihe-Talaud & 6 November 2018 & $M=5,1$ & $\begin{array}{l}\text { menyebabkan beberapa } \\
\text { rumah rusak ringan }\end{array}$ \\
\hline Manokwari Selatan & 28 Desember 2018 & $M=6,0$ & merusak beberapa rumah. \\
\hline
\end{tabular}

Sumber : Anwar Siswadi; (2018)

Salah satu sumber informasi yang diikuti dan dijadikan referensi di Indonesia salah satunya adalah $\begin{array}{llll}\text { Jurnal Geologi } & \text { Sumberdaya } & \text { Mineral } & \text { (JGSM) }\end{array}$ yang diterbitkan oleh Pusat Survei Geologi, Badan Geologi, Kementerian Energi dan Sumber Daya Mineral. Artikel dalam jurnal tersebut dapat ditulis dalam bahasa Indonesia maupun Inggris, dan telah terakreditasi oleh Lembaga Ilmu Pengetahuan Indonesia (LIPI) No. 596 / Akred / P2MI-LIPI / 03/2015 pada 2015. Sejak Februari 2017, JGSM telah diterbitkan dalam versi elektronik dengan e- ISSN: 25494759 sesuai dengan Surat LIPI No. 0005.25494759 / JI.3.1 / SK.ISSN / 2017.02 yang dimulai oleh Vol. 18, No. 1, Februari 2017. Jurnal ini diindeks dalam Indeks Publikasi Indonesia (IPI), Basis Data Jurnal Ilmiah Indonesia (ISJD) dan Google Cendekia, dan diterbitkan setiap tiga bulan yaitu pada bulan Februari, Mei, Agustus, dan November.

Sebagai salah satu sumber informasi di bidang gempa maka Jurnal Geologi dan Sumberdaya Mineral perlu dilakukan studi tentang bibliometrika yang dapat memberikan gambaran terhadap karakteristik jurnal tersebut (Sridevi, TR; 2014). Sampai saat ini berdasarkan hasil penelusuran dari berbagai sumber belum ada penelitian mengenai jurnal tersebut. Oleh karena itu dilakukan penelitian terhadap jurnal tersebut dengan tujuan hasilnya dapat dimanfaatkan oleh pengambil kebijakan terutama di bidang geologi. Oleh karena itu penelitian ini bertujuan untuk mengetahui: (1) Pertumbuhan publikasi Jurnal Geologi dan Sumberdaya Mineral periode 2014 - 2018, (2) Jumlah publikasi Jurnal Geologi dan Sumberdaya Mineral periode 2014 - 2018, berdasarkan Lembaga, (3) Pola kepengarangan dan kolaborasi pengarang, (4) Produktivitas pengarang, (5) Frekuensi kata kunci.

\section{Metode Penelitian}

Metode yang digunakan dalam penelitian ini adalah analisis bibliometrika yang dapat membantu peneliti dalam mempelajari isi bibliografi, analisis sitasi dari setiap artikel yang dimuat dalam Jurnal Geologi dan Sumberdaya Mineral Indonesia periode 2014- 2018. Pengumpulan data dilakukan dengan cara mengakses melalui alamat situs Jurnal Geologi dan Sumberdaya Mineral tersebut yaitu http://jgsm.geologi.esdm.go.id/index.php/JGSM. Selanjutnya dilakukan pencatatan terhadap jumlah artikel, jumlah pengarang, nama instansi, dan kata kunci. Langkah berikutnya adalah data diolah menggunakan Excel Spread Sheet serta dilakukan penghitungan persentase pada setiap variable yang dicatat. 


\section{Hasil dan Pembahasan}

Analisis bibliometrik dilakukan untuk mengevaluasi penelitian tanah longsor dari berbagai perspektif selama periode 1991-2014 berdasarkan pada basis data Indeks Citation Science-Expanded dan Social Citation Index (Lancaster, 1977; Gingras, Y., 2011; Marx and Bornmann 2016; Thomson Reuter, 2019). bibliometrik adalah bidang yang menggunakan matematika dan statistik, dari menghitung hingga kalkulus, untuk publikasi / penerbitan serta pola komunikasi dari distribusi informasi (Diodato, 1994). Berdasarkan sampel 10.567 artikel yang terkait dengan tanah longsor, analisis bibliometrik mengungkapkan keluaran ilmiah, kategori sains, judul sumber, distribusi geografis global penulis, penulis produktif, kolaborasi internasional, lembaga, dan evolusi temporal dari frekuensi kata kunci. Penelitian terkait tanah longsor telah mengalami pertumbuhan penting selama dua dekade terakhir. Geosains Multidisiplin, Teknik Geologi, dan Sumber Daya Air adalah tiga kategori sains utama, dan Geomorfologi adalah jurnal paling aktif selama periode yang disurvei. Cluster penulis utama dan wilayah penelitian terletak di Amerika Utara, Eropa Barat, dan Asia Timur. Amerika Serikat adalah kontributor utama penelitian tanah longsor global, dengan artikel paling independen dan kolaboratif, dan dominasinya juga dikonfirmasi dalam jaringan kolaborasi nasional / regional. Akademi Ilmu Pengetahuan China, Survei Geologi AS, dan Dewan Riset Nasional Italia adalah tiga lembaga penyumbang utama. Guzzetti F dari Dewan Riset Nasional Italia adalah penulis paling produktif, dengan artikel-artikel berkualitas tinggi. Sebuah analisis kata kunci menemukan bahwa penilaian kerentanan tanah longsor, stabilitas tanah longsor yang disebabkan oleh curah hujan dan gempa bumi, dan teknologi dan metode penelitian yang efektif adalah topik yang konsisten yang paling menarik perhatian selama periode penelitian. Beberapa kata kunci, seperti "kerentanan tanah longsor", "gempa bumi", "GIS", "penginderaan jauh", dan "regresi logistik", mendapat perhatian yang meningkat secara dramatis selama masa studi, yang kemungkinan menandakan tren penelitian di masa depan.

Analisis bibliometrik dilakukan untuk mengevaluasi publikasi penelitian di Asia Tengah dari 1990 hingga 2014 berdasarkan database Science Citation Index dan database Social Citation Index. Studi ini menyajikan tinjauan komprehensif lapangan dari aspek jurnal utama, kategori subjek, kata kunci luar biasa, negara terkemuka, lembaga dan penulis, serta kolaborasi penelitian. Teridentifikasi bahwa total 11.025 makalah diterbitkan dalam 2.356 jurnal dan telah ada perkembangan yang stabil selama 25 tahun terakhir untuk penelitian Asia Tengah. Geosains multidisiplin, Geokimia dan Geofisika, Paleontologi, Ilmu Lingkungan dan Zoologi adalah kategori subjek yang paling populer. Analisis kata kunci menunjukkan bahwa "Tien Shan", "perubahan iklim", "taksonomi”, "taksa baru”, dan "perawatan kesehatan" adalah topik yang menghasilkan minat dan perhatian paling besar. Selain itu, evolusi temporal kata kunci mengungkapkan pertumbuhan cepat "Sabuk Orogenik Asia Tengah" dan "kencan Zirkon UPB". Menurut analisis kekuatan penelitian, AS dan Akademi Ilmu Pengetahuan Rusia datang sebagai kontributor terkemuka dan memiliki posisi dominan dalam jaringan kolaborasi. Makalah ini merupakan upaya baru untuk lebih memahami perkembangan penelitian Asia Tengah. Temuan penelitian ini akan membantu peneliti meningkatkan kinerja (Wang et al., 2015).

doi: 10.14710/lenpust.v5i1.24116 
Penggunaan teknik analitik bibilometrik untuk memeriksa penelitian tsunami tidak ada dalam literatur. Tujuan dari penelitian ini adalah untuk melakukan analisis bibliometrik dari semua publikasi terkait tsunami di Science Citation Index (SCI). Parameter yang dianalisis meliputi jenis dokumen, bahasa publikasi, keluaran publikasi, kepengarangan, pola publikasi, distribusi kategori subjek, distribusi kata kunci penulis, negara publikasi, artikel yang paling sering dikutip, dan distribusi dokumen setelah tsunami Indonesia. AS dan Jepang menghasilkan 53\% dari total output di mana tujuh negara industri utama menyumbang mayoritas dari total produksi. Bahasa Inggris adalah bahasa yang dominan, terdiri atas $95 \%$ artikel. Model simulasi diterapkan untuk menggambarkan hubungan antara jumlah penulis dan jumlah artikel, jumlah jurnal dan jumlah artikel, dan persentase total artikel dan berapa kali kata kunci tertentu digunakan. Selain itu, pola publikasi tsunami dalam 8 bulan pertama setelah tsunami Indonesia terjadi pada tanggal 26 Desember 2004 menunjukkan tingginya persentase publikasi non-artikel dan lebih banyak dokumen yang diterbitkan dalam jurnal dengan faktor dampak yang lebih tinggi (Chiu, Wen-Ta and Ho, Yu-Shan; 2007).

Penelitian terhadap Journal of Geography and Geology periode 2010 - 2014 Dutta, M. (2019) yang berkaitan dengan pola kepengarangan, tempat bekerja penulis, distribusi geografis makalah, cakupan subjek dari artikel dan analisis kutipan dari artikel yang diterbitkan dalam jurnal tersebut. Studi ini menemukan bahwa mayoritas makalah adalah multi-pengarang yaitu pada kisaran 3-5. Artikel maksimum telah diterbitkan dari Universitas Afrika dan Asia. Sebagian besar ukuran kontribusi dibatasi hingga 10 halaman. Studi ini menunjukkan bahwa Geografi adalah kontributor subjek utama dalam jurnal ini. Kepengarangan kolaborasi dokumen yang dikutip sebagian besar adalah penulis berkolaborasi. Sebagai gambaran selama 2010 - 2014 penulis yang berkolaborasi 1-3 orang menghasilkan sebanyak 101 artikel, adapun penulis yang berkolaborasi sebanyak $3-5$ orang menulis sebanyak 76 artikel dan kolaborasi lebih dari 5 orang menghasilkan sebanyak 21.

Studi tentang penelitian gempa berdasarkan analisis bibliometrik dilakukan terhadap 84.051 dokumen yang diterbitkan di jurnal dan terbitan lainnya yang terdapat dalam Scientific Indeks Database bibliografi Indeks Citation Index (SCI) dan Indeks Ilmu Pengetahuan Sosial (CIPD) periode 1900-2010. Penelitian ini merangkum indikator publikasi yang signifikan dalam penelitian gempa, mengevaluasi kinerja penelitian nasional dan kelembagaan, dan mengadakan pengembangan penelitian gempa dari perspektif pelengkap. Hasil penelitian menunjukkan bahwa dari 84.051 publikasi, yang paling banyak jenis dokumen yang sering digunakan adalah artikel jurnal peer-review (67.932), yaitu 81,0\% dari total publikasi. Prosiding makalah $(6.150 ; 7.3 \%)$, abstrak $(3,515 ; 4.2 \%)$, materi editorial $(1.807 ; 2.2 \%)$, ulasan $(1.715 ; 2 \%)$ dan huruf $(928 ; 1.1 \%)$. Keempat kategori yang paling umum adalah geokimia dan geofisika (26.608 artikel; $28,3 \%$ dari total), geosains multidisipliner $(18,493 ; 19,7 \%)$, teknik sipil(7.735; 8,2\%), dan teknik geologi $(5.339 ; 5.7 \%)$, diikuti oleh konstruksi dan teknologi bangunan $(3.049 ; 3.2 \%)$, ilmu multidisipliner $(3.035 ; 3.2 \%)$, geologi $(2,369 ; 2,5 \%)$, oseanografi $(1.974 ; 2.1 \%)$, teknik mesin $(1,513$; $1,6 \%)$, dan teknik perminyakan $(1,452 ; 1,5 \%)$. Sebagai subjek teknik top ranking ini.Hasil penelitian 
menyarankan perkembangan yang solid dalam penelitian gempa, dalam hal peningkatan ilmiah produksi dan kolaborasi penelitian. Penelitian ini mengidentifikasi penulis, institusi, dan negara dalam penelitian gempa, dan ada distribusi publikasi yang tidak merata di Indonesia authorial, institusional, dan nasional. Kata kunci yang paling sering digunakan muncul dalam artikel tersebut adalah evolusi, California, deformasi, model, inversi, seismisitas, tektonik, struktur kerak, kesalahan, zona, litosfer, dan atenuasi.

\section{Distribusi artikel berdasarkan nomor terbitan}

Distribusi artikel berdasarkan nomor jurnal dapat diketahui dari tabel 2. Dari sejumlah 100 judul artikel yang diterbitkan selama 2014 - 2018, sebarannya merata pada setiap nomor dan volume, masing masing 20 persen. Terbitnya teratur sesuai salah satu persyaratan untuk akreditasi jurnal. Jurnal Geologi dan Sumberdaya Mineral (JGSM) adalah jurnal ilmiah Indonesia yang diterbitkan oleh Pusat Survei Geologi, Badan Geologi, Kementerian Energi dan Sumber Daya Mineral. Jurnal menerima artikel bahasa Indonesia atau bahasa Inggris. Artikel-artikel itu dipilih dan ditinjau oleh editor profesional dan peninjau sejawat kami. JGSM telah ditugaskan sebagai Majalah Periodik Ilmiah Terakreditasi oleh Lembaga Ilmu Pengetahuan Indonesia (LIPI) No. 596 / Akred / P2MI-LIPI / 03/2015 pada 2015. Sejak Februari 2017, JGSM telah diterbitkan dalam versi elektronik dari e- ISSN: 2549-4759 sesuai dengan Surat LIPI No. 0005.25494759 / JI.3.1 / SK.ISSN / 2017.02 yang dimulai oleh Vol. 18, No. 1, Februari 2017. Jurnal ini diindeks dalam Indeks Publikasi Indonesia (IPI), Basis Data Jurnal Ilmiah Indonesia (ISJD) dan Google Cendekia, isinya tersedia secara bebas dalam versi elektronik. JGSM diterbitkan setiap tiga bulan pada bulan Februari, Mei, Agustus, dan November.ISSN: 0853-9634 (cetak).

Tabel 2. Distribusi Artikel Berdasarkan Tahun

\begin{tabular}{lllll}
\hline Tahun & Volume & Jumlah Nomor & Jumlah artikel & Persentase \\
\hline 2014 & 15 & 4 & 20 & 20 \\
2015 & 16 & 4 & 20 & 20 \\
2016 & 17 & 4 & 20 & 20 \\
2017 & 18 & 4 & 20 & 20 \\
2018 & 19 & 3 & 20 & 20 \\
Jumlah & & $\mathbf{1 9}$ & $\mathbf{1 0 0}$ & $\mathbf{1 0 0}$ \\
\hline
\end{tabular}

\section{Pola kepengarangan}

Pola dapat dilihat pada tabel 3 berikut. Seluruh pengarang yang berkontribusi di dalam Jurnal Geologi dan Sumber daya Mineral berjumlah 101 orang dengan perincian sebagai berikut. Pengarang tunggal menulis 38 artikel, pengarang yang berkolaborasi berdua menulis 30 artikel, berkolaborasi bertiga menulis 17 artikel dan berempat menulis 14 artikel, berkolaborasi lima menulis 2 artikel. 
Tabel 3. Distribusi Artikel Berdasarkan Nomor

\begin{tabular}{llllllll}
\hline Nomor & & \multicolumn{9}{c}{ Volume } & Jumlah & Persentase \\
& $\mathbf{1 5}$ & $\mathbf{1 6}$ & $\mathbf{1 7}$ & $\mathbf{1 8}$ & $\mathbf{1 9}$ & & \\
\hline 1 & 5 & 5 & 5 & 5 & 5 & 20 & $20 \%$ \\
2 & 5 & 5 & 5 & 5 & 5 & 20 & $20 \%$ \\
3 & 5 & 5 & 5 & 5 & 5 & 20 & $20 \%$ \\
4 & 5 & 5 & 5 & 5 & 5 & 20 & $20 \%$ \\
Jumlah & $\mathbf{2 0}$ & $\mathbf{2 0}$ & $\mathbf{2 0}$ & $\mathbf{2 0}$ & $\mathbf{2 0}$ & $\mathbf{2 0}$ & $\mathbf{1 0 0 \%}$ \\
\hline
\end{tabular}

Tabel 4. Pola kepengarangan

\begin{tabular}{|c|c|c|c|c|c|c|}
\hline \multirow[t]{2}{*}{ Tahun } & \multicolumn{5}{|c|}{ Pengarang } & \multirow{2}{*}{ Jumlah } \\
\hline & 1 & 2 & 3 & 4 & 5 & \\
\hline 2014 & 9 & 5 & 2 & 4 & 0 & 20 \\
\hline 2015 & 10 & 7 & 2 & 0 & 1 & 20 \\
\hline 2016 & 9 & 5 & 4 & 2 & 0 & 20 \\
\hline 2017 & 5 & 5 & 6 & 4 & 1 & 21 \\
\hline 2018 & 5 & 8 & 3 & 4 & 0 & 20 \\
\hline Jumlah & 38 & 30 & 17 & 14 & 2 & 101 \\
\hline
\end{tabular}

\section{Tingkat Kolaborasi Pengarang}

Penghitungan tingkat kolaborasi pengarang dilakukan menggunakan persamaan dari Subramanyam (1983) yaitu :

$$
\mathrm{C}=\mathrm{Nm} / \mathrm{Nm}+\mathrm{Ns}
$$

$\mathrm{C}$ adalah tingkat kolaborasi peneliti dalam sebuah disiplin ilmu, nilai $\mathrm{C}$ tersebut berada pada interval nol sampai satu, (0 -1). Nm adalah total hasil penelitian dari pengarang dalam sebuah disiplin ilmu pada tahun tertentu yang dilakukan secara berkolaborasi. Dan Ns adalah total hasil penelitian dari pengarang dalam sebuah disiplin ilmu pada tahun tertentu yang dilakukan secara individual (Subramanyam, 1983).

Tabel 5. Distribusi Pola Kepengarangan Berdasarkan Tahun.

\begin{tabular}{|c|c|c|c|c|c|c|c|}
\hline \multirow{2}{*}{$\begin{array}{l}\text { Pola } \\
\text { Kepengarangan }\end{array}$} & \multicolumn{5}{|c|}{ Tahun } & \multirow[t]{2}{*}{ Jumlah } & \multirow[t]{2}{*}{ Persentase } \\
\hline & 2014 & 2015 & 2016 & 2017 & 2018 & & \\
\hline Tunggal & 9 & 10 & 9 & 5 & 5 & 38 & $37,62 \%$ \\
\hline Kolaborasi & 11 & 10 & 11 & 16 & 15 & 63 & $62,37 \%$ \\
\hline Jumlah & 19 & 20 & 19 & 21 & 20 & 101 & $100 \%$ \\
\hline
\end{tabular}

Mengacu kepada tabel 5 di atas maka tingkat kolaborasi adalah, $C=63 / 63+38=0,6$ Dengan nilai 0,6 (Nilai $\mathrm{C}$ lebih besar setengah dan kurang dari satu $(0,5<\mathrm{C}<1)$ maka dapat dikatakan bahwa hasil penelitian pada bidang tersebut dilakukan secara individual lebih sedikit dibanding dengan banyaknya hasil penelitian yang dilakukan secara berkolaborasi. Jadi pelaksanaan penelitian pada bidang tersebut memang sangat memerlukan bantuan dari disiplin ilmu lain atau lembaga penelitian lain. Menurut Subramanyam (1983: 35-36) tingkat kolaborasi peneliti tersebut berbeda - beda pada masing - masing 
disiplin ilmu. Frekuensi peneliti dalam melakukan kolaborasi dengan peneliti lain akan menentukan tingkat kolaborasi peneliti. Tingkat kolaborasi adalah bervariasi antara satu disiplin ilmu dengan disiplin ilmu lain, serta dipengaruhi oleh berbagai faktor seperti lingkungan riset, faktor demografis, dan jenis disiplin ilmu. Tingkat kolaborasi untuk bidang teknologi umumnya lebih tinggi bila dibandingkan dengan tingkat kolaborasi bidang humaniora.

\section{Produktivitas Pengarang}

Tabel 6. berikut ini, menunjukan sepuluh besar pengarang yang produktif yang dihasilkan selama periode 2014-2018.

Tabel 6. Sepuluh Pengarang Terproduktif

\begin{tabular}{lll}
\hline No & Pengarang & Jumlah Artikel \\
\hline 1 & Ronaldo Irzon & 8 \\
2 & Sigit Maryanto & 8 \\
3 & Asep Kurnia Permana & 5 \\
4 & Hermen Panggabean & 5 \\
5 & Imam Setiadi & 5 \\
6 & Joko Wahyudiono & 5 \\
7 & Kurnia & 5 \\
8 & Syaiful Bachri & 5 \\
9 & Budi Setyanta & 4 \\
10 & Dida Kusnida & 3 \\
\hline
\end{tabular}

Pengarang yang terproduktif dalam Jurnal Geologi dan Sumber Daya Mineral pada periode tahun 2014 sd. 2018 adalah Ronaldo Irzon dan Sigit Maryanto masing - masing 8 artikel, diikuti oleh Sigit Maryanto, Asep Kurnia Permana, Hermen Panggabean, Imam Setiadi, Joko Wahyudiono, Kurnia, Syaiful Bachri masing 5, Budi Setyanta 4 dan Dida Kusnida.

Guna melihat ahli geologi dan gempa di luar negeri, maka dapat dilihat dari penelitian Liu, X., dkk (2012) yang berjudul A bibliometric study of earthquake research : 1900-2010. Penulis yang produktif dalam penelitian gempa adalah Kanamori H dengan 169 artikel, diikuti oleh Panza GF dengan 127 artikel, McMechan GA dengan 126 artikel, Kennet BLN dengan 123, Hasegawa A dengan 122. Ada 30 penulis pada peringkat pertama dan 12 penulis pada peringkat kedua.

\section{Institusi Penyumbang Artikel pada Jurnal Geologi dan Sumber Daya Mineral}

Berdasarkan Tabel 7 berikut ini dapat diketahui bahwa sebanyak delapan institusi yaitu Pusat Survei Geologi Badan Geologi, Kementerian Energi dan Sumber Daya Mineral (73 artikel/ 73\%), Pusat Penelitian dan Pengembangan Geologi Kelautan, Program Studi Geofisika, Fakultas MIPA- Universitas Padjajaran (8 artikel / 8\%), Lembaga Ilmu Pengetahuan Indonesia, Pusat Penelitian Geoteknologi ( 7 artikel/7\%), Institut Geologi Kelautan Indonesia (3 artikel / 3\%), Museum Geologi, Bandung (3 artikel / 3\%), Institut Teknologi Bandung, Faculty of Mining and Petroleum Engineering (3 artikel/3\%), 
Universitas Gadjah Mada, Program studi teknik Geologi, Fakultas Teknik (2 artikel /2\%),Ikatan Ahli Geologi, Jakarta (2 artikel /2\%) menyumbangkan artikel mereka ke dalam jurnal tersebut.

Tabel 7. Frekuensi Jumlah Institusi yang Meneliti pada Jurnal Geologi dan Sumber Daya Mineral

\begin{tabular}{|c|c|c|c|}
\hline No & Institusi & Jumlah Artikel & Persentase \\
\hline 1 & $\begin{array}{l}\text { Pusat Survei Geologi Badan Geologi, } \\
\text { Kementerian Energi dan Sumber Daya } \\
\text { Mineral. }\end{array}$ & 73 & $73 \%$ \\
\hline 2 & $\begin{array}{l}\text { Pusat Penelitian dan Pengembangan Geologi } \\
\text { Kelautan, Program Studi Geofisika, Fakultas } \\
\text { MIPA- Universitas Padjajaran }\end{array}$ & 8 & $8 \%$ \\
\hline 3 & $\begin{array}{l}\text { Lembaga Ilmu Pengetahuan Indonesia, Pusat } \\
\text { Penelitian Geoteknologi }\end{array}$ & 6 & $6 \%$ \\
\hline 4 & Institut Geologi Kelautan Indonesia & 3 & $3 \%$ \\
\hline 5 & Museum Geologi, Bandung & 3 & $3 \%$ \\
\hline 6 & $\begin{array}{l}\text { Institut Teknologi Bandung, Faculty of Mining } \\
\text { and Petroleum Engineering }\end{array}$ & 3 & $3 \%$ \\
\hline 7 & $\begin{array}{l}\text { Universitas Gadjah Mada, Program studi } \\
\text { teknik Geologi, Fakultas Teknik }\end{array}$ & 2 & $2 \%$ \\
\hline 8 & Ikatan Ahli Geologi, Jakarta & 2 & $2 \%$ \\
\hline
\end{tabular}

Dari Tabel 7 dapat dilihat yang terbanyak menulis tentang Geologi dari Pusat Survei Geologi Badan Geologi, Kementerian Energi dan Sumber Daya Mineral, yaitu 78 artikel. Hal ini wajar karena Jurnal Geologi dan Sumberdaya Mineral merupakan jurnal yang diterbitkan oleh Pusat Survei Geologi Badan Geologi, Kementerian Energi dan Sumber Daya Mineral. Adapun di tempat ke dua adalah Pusat Penelitian dan Pengembangan Geologi Kelautan, Program Studi Geofisika, Fakultas MIPA- Universitas Padjajaran dengan jumlah atikel sebanyak 18 judul, adapun di tempat ke tiga diduduki oleh Pusat Penelitian Geoteknologi LIPI dengan jumlah artikel 7 judul.

\section{Frekuensi Kata Kunci}

Kata kunci merupakan salah satu sarana untuk menggambarkan tren arah penelitian, dan memberikan gambaran umum penelitian. Adapun berdasarkan hasil analisis kata kunci diperoleh sebanyak 240 jenis kata kunci (Tabel 7).

Tabel 8. Frekuensi Kata Kunci

\begin{tabular}{lll}
\hline No & Kata kunci (Deskriptor) & Jumlah \\
\hline 1 & Geological structure & 18 \\
2 & Basins (geology) & 13 \\
3 & Sedimentary rocks & 12 \\
4 & Geochemistry & 11 \\
5 & Limestone & 10 \\
6 & Hydrocarbon & 8 \\
7 & Petrography & 8 \\
\hline
\end{tabular}




\begin{tabular}{|c|c|c|}
\hline 8 & Tectonics & 8 \\
\hline 9 & Jawa Barat & 6 \\
\hline 10 & Plate tectonics & 6 \\
\hline 11 & Sedimentary basin & 6 \\
\hline 12 & Spectral analysis & 6 \\
\hline 13 & Geological research & 5 \\
\hline 14 & Gravity anomalies & 5 \\
\hline 15 & Volcanic rocks & 5 \\
\hline 16 & Jawa Tengah & 4 \\
\hline 17 & Petrology & 4 \\
\hline 18 & Coal & 3 \\
\hline 19 & Diagenesis & 3 \\
\hline 20 & Foraminifera & 3 \\
\hline 21 & Geology & 3 \\
\hline 22 & Kalimantan Barat & 3 \\
\hline 23 & Natural gas & 3 \\
\hline 24 & Oil gas & 3 \\
\hline 25 & Sedimentology & 3 \\
\hline 26 & Source rocks & 3 \\
\hline 27 & Andesite & 2 \\
\hline 28 & Aru Island & 2 \\
\hline 29 & Bintuni Basin & 2 \\
\hline 30 & Biostratigraphy & 2 \\
\hline 31 & Bouguer anomaly & 2 \\
\hline 32 & Carbon sequestration & 2 \\
\hline 33 & Carbonate rocks & 2 \\
\hline 34 & Cenozoic era & 2 \\
\hline 35 & Deformation structure & 2 \\
\hline 36 & Earthquakes & 2 \\
\hline 37 & Eastern Indonesia & 2 \\
\hline 38 & Freshwater & 2 \\
\hline 39 & Geodynamics & 2 \\
\hline 40 & Geological maps & 2 \\
\hline 41 & Geological sedimentation & 2 \\
\hline 42 & Geophysics & 2 \\
\hline 43 & Gravity & 2 \\
\hline 44 & Gravity analysis & 2 \\
\hline 45 & Gravity model & 2 \\
\hline 46 & Kalimantan & 2 \\
\hline 47 & Kalimantan Selatan & 2 \\
\hline 48 & Kalimantan Tengah & 2 \\
\hline 49 & Kalimantan Timur & 2 \\
\hline 50 & Kendal & 2 \\
\hline 51 & Kulon Progo & 2 \\
\hline 52 & Kutai Basin & 2 \\
\hline 53 & Landslide hazard analysis & 2 \\
\hline 54 & Moving average & 2 \\
\hline 55 & Palynology & 2 \\
\hline 56 & Petroleum & 2 \\
\hline
\end{tabular}




\begin{tabular}{|c|c|c|}
\hline 57 & Radar image & 2 \\
\hline 58 & Rare earth elements & 2 \\
\hline 59 & Remote sensing & 2 \\
\hline 60 & Riau & 2 \\
\hline 61 & Rock- eval pyrolysis & 2 \\
\hline 62 & Sandstone & 2 \\
\hline 63 & Stratigraphy & 2 \\
\hline 64 & Sulawesi & 2 \\
\hline 65 & Sulawesi Tenggara & 2 \\
\hline 66 & Soil mechanics & 1 \\
\hline 67 & Active continental margin & 1 \\
\hline 68 & Adsorption & 1 \\
\hline 69 & Alluvial fan & 1 \\
\hline 70 & Ambiguity & 1 \\
\hline 71 & Amphibole basalt & 1 \\
\hline 72 & Analytical hierarchy process & 1 \\
\hline 73 & Animal fossils & 1 \\
\hline 74 & Archaeology & 1 \\
\hline 75 & Array microtremor & 1 \\
\hline 76 & Asia & 1 \\
\hline 77 & Assaying & 1 \\
\hline 78 & Australia & 1 \\
\hline 79 & Banyumas & 1 \\
\hline 80 & Barito & 1 \\
\hline 82 & Biogas & 1 \\
\hline 83 & Bombana Kabupaten & 1 \\
\hline 84 & Brittlenses index & 1 \\
\hline 85 & Carbon dioxide & 1 \\
\hline 86 & Chemical composition & 1 \\
\hline 87 & Chemicophysical properties & 1 \\
\hline 88 & Chromite & 1 \\
\hline 89 & Cikepuh & 1 \\
\hline 90 & Claystones & 1 \\
\hline 91 & Climatic changes & 1 \\
\hline 92 & Dacite & 1 \\
\hline 93 & Deltaic sediment & 1 \\
\hline 94 & Digital elevation model & 1 \\
\hline 95 & Dipole-dipole interaction & 1 \\
\hline 96 & Disaster mitigation & 1 \\
\hline 97 & Electrical resistivity tomography & 1 \\
\hline 98 & Enhanced Oil & 1 \\
\hline 99 & Eocene Epoch & 1 \\
\hline 100 & Eocene-Oligocene & 1 \\
\hline 101 & Exinite & 1 \\
\hline 102 & Fission trck dating & 1 \\
\hline 103 & Flores & 1 \\
\hline 104 & Fluvial sediment & 1 \\
\hline 105 & Formation pressure & 1 \\
\hline
\end{tabular}




\begin{tabular}{|c|c|c|}
\hline 106 & Fossil & 1 \\
\hline 107 & Fossil fuel & 1 \\
\hline 108 & Fossil hominids & 1 \\
\hline 109 & GC-MS analysis & 1 \\
\hline 110 & Gemstones & 1 \\
\hline 109 & GC-MS analysis & 1 \\
\hline 111 & Geodiversity & 1 \\
\hline 112 & Geographic information system & 1 \\
\hline 113 & Geological mapping & 1 \\
\hline 114 & Geological structural element & 1 \\
\hline 115 & Geological subsurfaces & 1 \\
\hline 117 & Geomorphology & 1 \\
\hline 118 & Gold & 1 \\
\hline 119 & Gold mining & 1 \\
\hline 120 & Granite & 1 \\
\hline 121 & Granitic rocks & 1 \\
\hline 122 & Ground penetrating radar & 1 \\
\hline 123 & Gunung Gede & 1 \\
\hline 124 & Gunung Geulis & 1 \\
\hline 125 & Hydrothermal minerals & 1 \\
\hline 126 & Indonesia & 1 \\
\hline 127 & Induced polarization & 1 \\
\hline 128 & Intrusive rocks & 1 \\
\hline 129 & Irian Jaya & 1 \\
\hline 130 & Jasper & 1 \\
\hline 131 & Jawa & 1 \\
\hline 132 & Jawa Barat Basin & 1 \\
\hline 133 & Jawa Timur & 1 \\
\hline 134 & Kabupaten Gunung Kidul & 1 \\
\hline 135 & Kabupaten Pekalongan & 1 \\
\hline 136 & Klaten & 1 \\
\hline 137 & Lake sediments & 1 \\
\hline 138 & Lampung Barat & 1 \\
\hline 139 & Landslides & 1 \\
\hline 140 & Lateritic nickel & 1 \\
\hline 141 & Laut Maluku & 1 \\
\hline 142 & Leuwidamar & 1 \\
\hline 143 & Madiun & 1 \\
\hline 144 & Magnetic anomalies & 1 \\
\hline 145 & Magnetic field anomaly & 1 \\
\hline 146 & Magnetic susceptibility & 1 \\
\hline 147 & Magnetisms & 1 \\
\hline 148 & Maluku & 1 \\
\hline 149 & Maluku Utara & 1 \\
\hline 150 & Mandibular ramus & 1 \\
\hline 151 & Merapi volcano & 1 \\
\hline 152 & Mesozoic & 1 \\
\hline 153 & Mesozoic rock & 1 \\
\hline 154 & Methane & 1 \\
\hline
\end{tabular}




\begin{tabular}{|c|c|c|}
\hline 155 & Microcrystalline & 1 \\
\hline 156 & Microscopy & 1 \\
\hline 157 & Microseisms & 1 \\
\hline 158 & Mineral resources & 1 \\
\hline 159 & Mineralisation & 1 \\
\hline 160 & Mineralization & 1 \\
\hline 161 & Mineralogy & 1 \\
\hline 162 & Miocene Epoch & 1 \\
\hline 163 & Mount Padang & 1 \\
\hline 164 & Nannoplankton & 1 \\
\hline 165 & Natural disasters & 1 \\
\hline 166 & Near infra red & 1 \\
\hline 168 & Nusa Tenggara Timur & 1 \\
\hline 169 & Oil drilling & 1 \\
\hline 171 & Oligicene Epoch & 1 \\
\hline 172 & Ore microscopic & 1 \\
\hline 173 & Organic matter & 1 \\
\hline 171 & Oligicene Epoch & 1 \\
\hline 174 & Organic mterials & 1 \\
\hline 175 & Paleomagnetis & 1 \\
\hline 176 & Paleovolcano & 1 \\
\hline 177 & Pangandaran & 1 \\
\hline 178 & Papua & 1 \\
\hline 179 & Papua Barat & 1 \\
\hline 180 & Pari Island & 1 \\
\hline 181 & Precious metal & 1 \\
\hline 182 & Provinsi Sumatra Selatan & 1 \\
\hline 183 & Pulau Jawa & 1 \\
\hline 184 & Pulau Singkep & 1 \\
\hline 185 & Pulau Timor & 1 \\
\hline 186 & Pyrolysis & 1 \\
\hline 187 & Rainfall & 1 \\
\hline 188 & Rajamandala & 1 \\
\hline 189 & Reference materials & 1 \\
\hline 190 & Resonant frequency & 1 \\
\hline 191 & River sediments & 1 \\
\hline 192 & Rock- eval pyrolysis & 1 \\
\hline 193 & Rock mass (ground) & 1 \\
\hline 194 & Salawati Basin & 1 \\
\hline 195 & Scanning electron microscopy & 1 \\
\hline 196 & Seafloor & 1 \\
\hline 197 & Sediment core & 1 \\
\hline 198 & Sedimentary & 1 \\
\hline 199 & Sedimentary process & 1 \\
\hline 200 & Sedimentary structure & 1 \\
\hline 201 & Shale & 1 \\
\hline 202 & Shear wave velocity & 1 \\
\hline 203 & Silica & 1 \\
\hline
\end{tabular}




\begin{tabular}{|c|c|c|}
\hline 204 & Singkawang Basin & 1 \\
\hline 205 & Solvent impregnated resin & 1 \\
\hline 206 & Sorong & 1 \\
\hline 207 & Spatial analysis & 1 \\
\hline 208 & Stegodon & 1 \\
\hline 209 & Stratigraphy (sequence of layers) & 1 \\
\hline 210 & Stream sediments & 1 \\
\hline 211 & Structure formation & 1 \\
\hline 212 & Submarine fans & 1 \\
\hline 213 & Sukabumi & 1 \\
\hline 214 & Sulawesi Timur & 1 \\
\hline 215 & Sumatera & 1 \\
\hline 216 & Sumatera Selatan & 1 \\
\hline 217 & Sumatera Tengah Basin & 1 \\
\hline 218 & Sweden & 1 \\
\hline 219 & Tailings & 1 \\
\hline 220 & Tectonic movements & 1 \\
\hline 221 & Timor Tengah Selatan & 1 \\
\hline 222 & Tin mines & 1 \\
\hline 223 & Topography & 1 \\
\hline 224 & Total organic carbon & 1 \\
\hline 225 & Total organic matter & 1 \\
\hline 226 & Tuff & 1 \\
\hline 227 & Vegetation & 1 \\
\hline 228 & Vertebrata & 1 \\
\hline 229 & Vitrinite & 1 \\
\hline 230 & Volcanic activity & 1 \\
\hline 231 & Volcanostratigraphy & 1 \\
\hline 232 & Water availability & 1 \\
\hline 233 & Water use & 1 \\
\hline 234 & West Papua & 1 \\
\hline 235 & West Timor & 1 \\
\hline 236 & Wildlife conservation & 1 \\
\hline 237 & $\mathrm{X}$ ray fluorcence & 1 \\
\hline 238 & X-Ray Diffraction & 1 \\
\hline 239 & X-Ray Fluorescence & 1 \\
\hline \multirow[t]{2}{*}{240} & Yogyakarta & 1 \\
\hline & TOTAL & 415 \\
\hline
\end{tabular}

Berdasarkan Tabel 8 dapat diketahui bahwa frekuensi kata kunci pada Jurnal Geologi dan Sumber Daya Mineral tahun 2014 sampai dengan 2018 adalah sebanyak 415 kata kunci. Adapun kata kunci yang terbanyak adalah geological structure berjumlah 18, diikuti oleh kata kunci Basins (geology) 13, selanjutnya sedimentari rocks berjumlah 12, geochemistry 11,limestone 10, Hydrocarbon, Petrography, Tectonics, masing-masing 8, Jawa Barat, Plate tectonics, Sedimentary basin, Spectral analysis masingmasing 6, adapun kata kunci selengkapnya dapat dipelajari dari Tabel 7 tersebut. Dengan demikian tren penelitian geologi periode 2014 - 2018 adalah berkaitan dengan struktur geologi. 


\section{Simpulan}

Berdasarkan studi bibliometrik dari Jurnal Geologi dan Sumber Daya Mineral tahun 2014 sampai dengan 2018, dapat disimpulkan bahwa; jumlah artikel yang dipublikasikan sebanyak 100 judul, dengan pengarang berkolaborasi lebih banyak dibadingkan pengarang tunggal. Adapun pengarang paling produktif adalah Ronaldo Irzon dan Sigit Maryanto, dengan institusi penyumbang artikel terbanyak adalah Pusat Survei Geologi Badan Geologi Nasional Kementerian ESDM, dan tren penelitian adalah berkaian dengan struktur geologi.

\section{Daftar Pustaka}

Anwar Siswadi. 2018. 23 Gempa Merusak di Indonesia Sepanjang 2018. Diakses dari https://tekno.tempo.co/read/1159731/23-gempa-merusak-di-indonesia-sepanjang-

2018/full\&view=ok. Pada 08 Mei 2019.

Chiu, Wen-Ta and Ho, Yu-Shan. 2007. "Bibliometric analysis of tsunami research". Scientometrics, vol. 73, no. 1, pp. 3-17.

Diodato, Virgil. 1994. Dictionary of bibliometrics. New York : The Hawoorth Press.

Dutta, Madhushree. 2018. "Trends in the Journal of Geografi and Geology: a Five - Year Bibliometrics Analysis". International Journal of Humanities and Social Science Invention, vol.8 no. 8, January.

Gingras, Yves. 2011. .Bibliometrics and research evaluation: an overview. Diakses dari: https://issek.hse.ru/data/2011/05/30/1212612098/Bibliometrics-Evaluation.Intro.pdf, 08 . Pada 08 Mei 2019.

Lancaster, Frederick Wilfrid. 1977. Measurement and evaluation of library services. Washington: Information Resources.

Liu, Xiangjan, Zhan, F. Benjamin., Hong, Song., Niu, Beibei., \& Liu, Yaolin. 2012. "A bibliometric study of earthquake research: 1900-2010”. Scientometrics, vol. 92, no. 3, pp. 747-765.

Marx, Werner and Lutz Bornmann. 2016. "Change of Perspective: Bibliometrics from the Point of View of Cited References - a Literature Overview on Approaches to the Evaluation of Cited References in Bibliometrics." Scientometrics 109(2):1397-1415.

National Geographic Idonesia. 2014 .Hidup dalam cincin api National Geographic Indonesia. 2012-1214.http.:.//nationalgeographic.grid.id/read/13283321/hidup-mati-di-negeri-cincin- api?page=all . Diakses tanggal 2019-02-25.

Xiaoli, Lu and Dong, Yongliang. 2018. "Intellectual structure of geology research in China: Abibliometric analysis of the funded projects of NSFC". Procedia Computer Science, vol. 139, pp. $417-423$.

Sridevi, T.R. 2014. "Research Evaluation of Indian Journal of Cancer: A Bibliometric Study".Research Journal of Library Sciences, vol. 2, no. 2, pp. 1-5.

T, Frank. 2018. What is Geology? - Definition, History, Facts \& Topics. Diakses dari https://study.com/academy/lesson/what-is-geology-definition-history-facts-topics.html. Pada 24 Maret 2019. 
Thomson Reuter. 2019. White Paper: Using Bibliometrics.A guide to evaluating research performance with citation data scientific. Diakses dari ips.clarivate.com/m/pdfs/325133_thomson.pdf, diakses 08 Mei 2019. Pada 08 Mei 2019.

Lowa State University Library. 2019. OECD Glossary of Statistical. Diakses dari https://instr.iastate.libguides.com/c.php?g=49332\&p=318077. Pada 08 Mei 2019.

Wang, Li xian, Xi Chen, Anming Bao, Xiaoyun Zhang, Miao Wu, Yun Hao, and Jingjing He. 2015. “A bibliometric analysis of research on Central Asia during 1990- 2014”. Scientometrics, vol. 105, no. 2, pp. $1223-1237$. 